Original Research Paper

\title{
An Analysis of the Influence of Ownership Structure, Investment, Liquidity and Risk to Firm Value: Evidence from Indonesia
}

\author{
${ }^{1}$ Maryam Mangantar and ${ }^{2}$ Muhammad Ali \\ ${ }^{I}$ Faculty of Economics and Business, Sam Ratulangi University, Manado, Indonesia \\ ${ }^{2}$ Faculty of Economics and Business, Hasanuddin University, Makassar, Indonesia
}

\author{
Article history \\ Received: 09-03-2015 \\ Revised: $30-09-2015$ \\ Accepted: 27-10-2015 \\ Corresponding Author: \\ Maryam Mangantar \\ Faculty of Economics and \\ Business, Sam Ratulangi \\ University Manado, Indonesia \\ Email: marjam.mangantar@gmail.com
}

\begin{abstract}
The aims of this study is to determine the influence of ownership structure, investment, stock liquidity and risk stock to operating performance, Good Corporate Governance (GCG) and firm value on the manufacturing sector listed in Indonesian Stock Exchange (IDX). The research results are; the ownership structure have a positive significant effect to operating performance and the risk stock have a negative significant effect on operating performance and operating performance have positive insignificant effect on firm value. The ownership structure have a significant effect on corporate governance and corporate governance have a significant effect on firm value. However, investment, stock liquidity and risk stock have a negative insignificant effect on corporate governance. Stock liquidity have a negative significant effect on firm value, however ownership structure and investment have insignificant effect on firm value. Special findings from this research are that there is gradual process in influencing firm value so that corporate governance has the role as intervening variable, which is the variables moderating the effects of ownership structure in affecting firm value.
\end{abstract}

Keywords: Ownership Structure, Investment, Stock Liquidity, Risk Stock, Operating Performance, GCG, Firm Value

\section{Introduction}

The company represents the union between the various interests of shareholders and management that aims value maximize of the company. It that means value maximize of shareholder wealth is the ultimate goal of the company. Improved corporate value indicates increasing shareholder wealth. A postulate of sound investing is that an investor does not pay more for an asset than its worth (Damodaran, 2006). Company is above the market value of debt securities and outstanding equity investor perceptions and the level of success that is often associated with the company's share price (Keown et al., 2004).

The purpose of the prosperity shareholder reached their advantages or yield of each share is embedded on investment. The advantages obtained are derived from the net income of the company and also an increase in the price of shares on the share exchange. Rising share prices mean increased Firm Value itself (the market value of the firm). An enterprise value of investor's perception level of success companies are often associated with share price. High share price makes the firm value is also high. Firm value high will make the market believe not only in the firm's current performance but also on the company's future prospects.

The value of a company depends solely on income in the future, hence information about the success of a company in profit will largely determine the Firm Value. Moreover, the company will also be reflected in its share price (Fama, 1978). The higher share price affecting to the higher firm's value. The share price is the market price for shares of a corporation that is formed due to meeting the demand and supply in the event of a transaction in the share market. Share that have high liquidity or attractive to investors and may increase the share price.

Several studies discuss the structure of corporate ownership relationship with value creation (Jensen and Meckling, 1976; Cho, 1998; Iturriaga and Sanz, 2001; 
Cole and Mehran, 1998; Eisenberg et al., 1998; Barnhart and Rosenstein, 1998; Fuers and Kang, 2000). Ownership structure can be explained from two angles (Iturriaga and Sanz, 2001), namely: Agency approach and asymmetric information approach. Agency approach considers the ownership structure as an instrument or tool to reduce conflicts of interest among the various holders of claims. Approach of looking at the information imbalance mechanism ownership structure as a way to reduce the information asymmetry between insiders and outsiders through the disclosure of information in the capital markets (Leland and Pyle, 1977)

Anderson et al. (2003) argues that the ownership structure will lead to conflict. Ownership structure is closely connected with the conflicts that can affect the operating performance and the performance of the company. It must have been the reason why the research on the impact of ownership structure becomes important to study.

Good corporate governance in countries such as America and England in contrast to Southeast Asian countries (Gugler et al., 2004). In these countries, relatively more dispersed share ownership, so that each individual investor has limitations in monitor managers. In such circumstances this, the main conflict in corporate governance only occurs between managers and shareholders.

In Southeast Asian Countries, share ownership generally centered, so that the conflict occurred between minority shareholders and holders share the majority of which has control/supervision large. Empirical evidence shows that Indonesia is a country that have involved unique characteristics, such as has a high concentration of ownership, the manager ownership low and the lack of regulations to protect investors (Setiawan, 2004). Indonesia also has a unique regulatory framework (purposes financial reporting is relatively not too tight, as well as the structure unique corporate governance (corporate escorted by some members of the family).

In Indonesia, the ownership of companies listed on the share is very centralized. This in nature are characteristic for a company that developing as well as in the growth of capital markets. Company conglomerate on this time entering difficult times, because the company listed in the Indonesia Stock Exchange discrete unique is the high ownership concentration, ownership to manager low and the manager of the company is a member the family of the owner who has the ownership concentration high and there is no difference between the owner with manager.

Several previous studies in Indonesia found that debt over equity ownership has a relationship with manager's problem of morale threat (Huey, 1994; Wibisono, 1998). Ownership leadership manager low make the manager has the inability to determine the company policy. The company's policy is influenced by the spread between the share parties outside the company with company managers. Ownership managers can be a source of strength for the manager so into the same position as shareholders as well as to equate the interests of managers and corporate governance shareholders, so little possibility for managers to performance action that different from the desire of shareholders (Aggarwal and Samwick,1999; Morck et al., 1988).

Firm Value also affected by investment decisions. Fama (1978) says that the Firm Value is solely determined by the investment decisions. Investment decisions are not made carefully will lead to cost remains in the form of high capital costs which will ultimately impact the performance of the company. Capital structure decisions directly affect the magnitude of shareholders risk and their rate of return or the rate of expected (Brigham and Houston, 2003). Each financing and investment will affect to the risk of the company's cash flow. In generally, the manager will make a decision and financing investments designed to maximize corporate value through share price maximization.

Based on the contradiction theory and existing research results, the research is important because the ownership structure, investment, stock liquidity and risk stock reflecting the company's value impact directly or indirectly and whether these effects are significant or not. The study also wanted to test whether the effect of these variables caused by no mediation of other variables. Variables selected as mediating or intervening variable is the operating performance and the chosen of these two variables based on the understanding that operating performance can provide accurate information on the company's success in generating operating profits of corporate governance while able to reduce conflicts of interest between managers and shareholders. With improve corporate governance in the company will increase the performance of the company (Black et al., 2009). Company with a high level of corporate governance can generate high performance (Drobez, 2003), is also a high correlation between the indicators of corporate governance mechanisms the performance and market valuation. In other words, the application of corporate governance in the company will increase the performance of the company itself. The results of these studies can be explained empirically that corporate governance is measured differently, have a positive effect on firm performance.

The Object research which selected in this study are the companies in the manufacturing sector listed on the Indonesia Stock Exchange. The first reason chosen types of manufacturing, because it is too many categories company listed than other types of other businesses and has similar characteristics. The company is listed on the Indonesia Stock Exchange in 2011 as 442, of that 
number $131(29.63 \%)$ of them is a manufacturing company, so the ability to analyze the sector is expected to provide conclusions that can be compared from one company to another company. The second reason, the existence of regulations that require companies to provide clear information compared to companies that are not listed on the Indonesia Share Exchange and the company is required to report its financial report to Capital Market Supervisory Agency (Bapepam) and publish it. The third reason that the company on manufacturing sector has a more simple disclosure than companies in other sectors, such as the financial sector.

With such considerations described in the previous section the implementation of this study are: First; investigate the direct effect of ownership structure, investment, stock liquidity, risk stock, the operating performance, corporate governance and the Firm Value in a proxy with Economic Value Added (EVA) companies listed on the Indonesia Stock Exchange. Secondly; investigate the effect of indirect ownership structure, investment, share liquidity, share risk and corporate governance on firm value through operating performance of companies listed on the Indonesia Stock Exchange. Third, investigate the indirect effect of ownership structure, investment, shtock liquidity and risk stock to firm value through corporate governance companies listed on the Indonesia Stock Exchange.

With these considerations the researcher wishes to conduct research on the effect of ownership structure, investment, share liquidity, share risk to operating performance, corporate governance and the Firm Value listed on the Indonesia Stock Exchange with a ten-year period of observation the year 2001-2010.

\section{Theoretical Framework}

There are many theories which explain the value of the firm. The study was based on a grand theory that has been well established that financial Firm value theory (The Market Value of the Firm Theory). This study departs from the standpoint of financial management experts prior to the period 1976, which examines the behavior of the company in terms of "economic models of the firm". This model does not recognize the aspect or human behavior as a determinant of corporate behavior. Jensen and Meckling (1976) provide a fundamental contribution to the agency cost models of the firm. This model acknowledges the human role in the behavior of the company that the agency is to minimize conflict by increasing managerial ownership in the company. Ross et al. (1993) states that the greater the ownership of the management, the management company will tend to try to improve performance for the benefit of shareholders and for their own interests. Separation of ownership by the principal to control the agent in an organization tend to cause conflict between the principal to agency. Cho (1998); Machfoedz and Suranta (2003) stated that the relationship of managerial ownership structure and firm value is non-monotonic relationship Non monotonic relationship between managerial ownership and firm value due to the incentives that are owned by the manager and they tend to try to do the alignment of interests with outside owners by increasing their stake if the Firm Value is derived from increased investment. Reduce agency cost can be done with strict control, so that managers will use the debt at a low level to anticipate the possibility of financial distress and bankruptcy risk. Demand hypothesis explains that the company is controlled by the insider using large amounts of debt to fund the company. The existence of a large insider ownership, it is expected to maintain effective control over the company Supply hypothesis explains that the company is controlled by the insider has a small debt agency cost thereby increasing the use of debt. The more concentrated share ownership, supervision of the owners of the more effective management. Management will be more careful in obtaining a loan, because increasing the amount of debt that will lead to financial distress. The occurrence of financial distress will lead the company's value will decline, thereby reducing the owners prosperity. Watts and Zimmerman (1990) states that the financial statements are made is expected to minimize conflicts among the parties concerned. In perspective the agency theory, agents are risk adverse and the selfish will tend to allocate resources (invest) which do not increase the Firm Value. This agency problem would indicate that the value will go up if the company can control the behavior of the owner of the company so as not to waste management company resources, both in the form of investment that is not feasible, nor in the form of shirking. With the financial statements as reported by the agency performance accountability, the principal can assess, measure and monitor the extent to which the agency is working to improve their welfare and to provide compensation to the agent. One mechanism that is expected to control agency costs by implementing good corporate governance. Kaen (2003) stated that corporate governance is essentially concerned the issue of who should control the activities of the corporation and why should be done to control the activities of the corporation. The definition of who are the shareholders, while the "why" is because of the relationship between the shareholders of the various parties interested in the company. Corporate governance is a system that regulates and controls the company which is expected to provide and enhance the company's value to shareholders. Thus, the implementation of good corporate governance is believed to increase the Firm Value.

Morck et al. (1988) in Barnhart and Rosenstein (1998), which examines the relationship between managerial ownership and board composition on firm value commissioner finds that firm value increases with the increase in managerial ownership up to $5 \%$, then decreases as managerial ownership of $5-25 \%$ and then increased again in line with the increase in managerial 
ownership on an ongoing basis. Black et al. (2003) argued that firstly, the company will be better managed so that it can be more profitable higher dividends. Secondly, caused by outside investors to assess earnings or dividends equal to the higher of companies that implement better corporate governance. The results showed that there was no evidence that companies with good corporate governance is more profitable or pay higher dividends, but there is evidence that investors assess current earnings or dividends equals higher for companies that implement better corporate governance.

\section{Literatures Review}

Several studies on the operating performance of the going public company, among others, Jain and Kini (1994) argues that an IPO led to dilution of share ownership and therefore increase agency costs. The decrease in ownership occurs when the management of the company made the transition from private ownership to public ownership is likely to lead to agency problems as described Jensen and Meckling (1976). Firm operating performance can reduce the chances of a manager to get the incentives, consequently Jain and Kini (1994) found evidence of post-IPO decline in operating performance in the U.S. in 1976 to 1988. Decrease is due to the decrease incentives for managers. Agency costs by dilution of ownership, when it became a public company, can be reduced if the previous owners and management retain a higher portion of the company after the IPO. Mikkelson et al. (1997) examined the going public company during the years 1980 to 1983 found that the change in operating performance has no relationship with managerial ownership. Instead the changes in operating performance after going public mainly explained by the size and age of the company.

Research on the relationship between managerial ownership with different operating performance among some researchers. Demsetz and Lehn (1985; McConnell and Servaes, 1990; Morck et al., 1988; Short et al., 1999) test that affect operating performance, no change in performance. If there is a cross-sectional relationship between ownership and performance, then the change of ownership should also correlated with changes in the performance, for example, if managerial ownership is positively related to firm performance, then tenure should lead to managerial company performance. Implicitly assumed that the relationship between the change in ownership and changes in firm performance is linear (Houlthausen and Larcker, 1996; Kaplan, 1989; Muscarella and Vetsuypens, 1990; Smith, 1990).

A linear relationship can explain the conflict in findings between Jain and Kini (1994) investigated the linear relationship between operating performance with managerial ownership, while Mikkelson et al. (1997) consider the non-linear relationship by including the square of ownership as an important variable. Jain and Kini (1994) found a positive relationship between the ownership of the firm operating performance. Further studies that examine the effect of ownership structure on operating performance, especially in emerging markets IPOs in markets of developing countries where the IPO is a very important source of funding. The characteristic of capital markets of developing countries, the company is entering the capital market in Thailand is owned, managed and supervised individual, family and partner. Bank loans and share offering to the public is the primary funding source. The level of information asymmetry among market players is higher than in countries forward. Hence capital structure has a more important role in the achievement of firm performance in developing countries than in developed countries.

Bhide (1993) analyze the relationship between share liquidity with asymmetry of information on companies in the USA concluded that liquidity is the driving factor for shareholders who will sell their shares. The findings of another active shareholder liquidity squeeze share by creating a problem of information asymmetry. .

Jensen and Meckling (1976) concluded that the separation between ownership and control in corporations will minimize agency costs and vice versa if there is no separation between ownership and management of the agency cost will increase. Furthermore, the Agency said the cost depends on the performance and evaluation of the manager and the owner of the company with monopoly power have the same incentives to limit divergence managers in enterprise value.

Lemmon and Lins (2003) examines the effect of ownership structure, corporate governance on firm value in Hong Kong, said that the share return is low on pyramidal ownership. Furthermore, it was found that the structure of ownership and corporate performance can be used as a guide to the role and design firm corporate governance and legal institutions in developing countries.

Cho and Kim (2007) examined the outsiders directors, ownership structure and profitability of companies in Korea, concluded that the control shareholders have a positive role in the management of the company. Other finding that the managers of companies in Korea as well as a dependency to the owner who has the controlling shareholders.

Jung and Lee (2009) examined the ownership structure, corporate governance and firm value in China's listed companies states that share ownership by government negatively affecting the firm value. Institutional ownership is negatively significant effect on firm value. Effective monitoring of institutional ownership have effect on the corporate governance and firm value. Furthermore, the low performance of the company occurred in companies with share ownership by the government. 
Demsetz and Villalonga (2001) examines Ownership structure and the corporate governance in USA, concluding that insider ownership has a negative association with the ratio of capital to total sales, but there is a positive correlation ratio of advertising to sales and operating income to sales ratio. Other findings, there is no relationship between the board commissioned the company's performance, but there is a significant non-monotonic relationship between managerial ownership with firm performance. There is a significant positive relationship between firm performance with managerial ownership.

Cole and Mehran (1998) studied the effect of changes in ownership structure on firm performance in the U.S, concluded that after the conversion and the limitation of the ownership structure, the company's performance increases. There is a positive relationship between changes in performance and changes in the structure of share ownership by managers, however, have a negative relationship with share ownership by employees.

Lyandres et al. (2008) examines the new issues puzzle company in the U.S stating that the investment is the driving force behind the new issues puzzle. Shortterm share investments and long payback gained an average of $0.57 \%$ per month.

Siallagan and Machfoedz (2006) investigated the mechanism of corporate governance, earnings quality and firm value on the share exchange concluded that the positive effect of earnings quality on firm value. Corporate governance mechanisms are statistically significant effect on firm value.

Demsetz and Lehn (1985) concluded in his study that there is no significant relationship between ownership concentration and accounting profit rate. Conceptually and empirically the structure of corporate ownership varies systematically and consistently in order to maximize the firm value.

Amman et al. (2009) examined in 22 developing countries concluded that there is a negative relationship between board independence with the firm value. There is a significant relationship between corporate governance by market value manufacturing companies. The characteristics of a country greatly affects aspects of corporate governance. While Loderer and Roth (2005) concluded that there is a negative relationship between the board of directors with the performance of the company.

The present study examines the effect of ownership structure, investment, liquidity risk and shares risk to operating performance, Good Corporate Governance (GCG) and firm value of the manufacturing sector that listed in Indonesian Stock Exchange (IDX). On the basis of theoretical framework of Isshaq (2009) and previous empirical result we have developed the following hypotheses between firm value as an endogenous variable and ownership structure, investment, share liquidity, share risk, operating performance and GCG as an exogenous variable:

H1a: The ownership structure has significant positive effect on the operating performance

H1b: Investment has significant positive effect on the operating performance

H1c: Stock liquidity has significant positive effect on operating performance

H1d: Risk stock has significant positive effect on the operating performance

H1e: Corporate governance has significant positive effect on the operating performance

H2a: The ownership structure has significant positive effect on corporate governance

$\mathrm{H} 2 \mathrm{~b}$ : Investment has significant positive effect on corporate governance

$\mathrm{H} 2 \mathrm{c}$ : Stock liquidity has significant positive effect on corporate governance

H2d: Risk stock has a significant positive effect on corporate governance

H3a: The ownership structure has significant positive effect on the Firm Value

$\mathrm{H} 3 \mathrm{~b}$ : Investment has significant positive effect on the Firm Value

$\mathrm{H} 3 \mathrm{c}$ : Stock liquidity has significant positive effect on the Firm Value

$\mathrm{H} 3 \mathrm{~d}$ : Stock risk has significant positive effect on the Firm Value

H3e: Operating performance significant positive effect on the Firm Value

H3f: Corporate governance has significant positive effect on the Firm Value

\section{Research Methodology}

According to the existing literature the Value of Company have been analyzed under the theory of the Firm Value Theory and the Agency Theory. These theory empirically tested the effect of ownership structure, investment, share liquidity and share risk to operating performance, GCG and firm value using data mostly based on Manufacturing company published financial statement listed at Indonesian Stock Exchange. Moreover Path analysis is used to develop the statistical framework. This section includes the sample data and the variable used in investigation and distinguishing the effect of the value of the manufacturing sector in Indonesia by using statistical techniques.

\section{Data Description}

Data used in this study is a secondary data that have been published, the data in the form of financial ratios calculated from the elements contained in the Annual Financial Statements of the company in the manufacturing sector are published every end of the period of each year starting in 2000 until the year 2010 . 


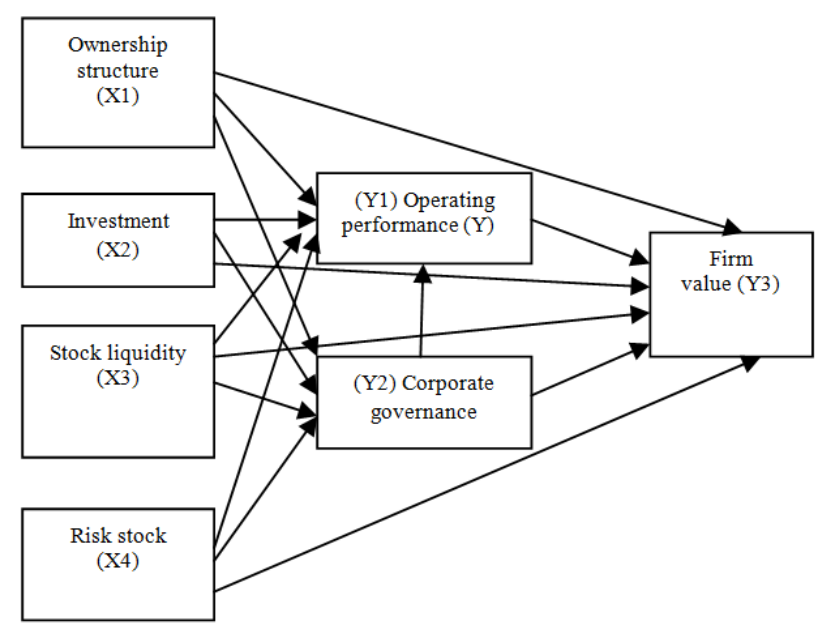

Fig. 1. Diagram of model

These data in the form of Balance Sheet, Statement of Loss/profit, shareholder list, the Jakarta Composite Index (JCI). Sources of data obtained from the Indonesian Capital Market Directory (ICMD) and the Web site the Indonesia Stock Exchange (IDX), the Capital Market Supervisory Agency (Bapepam), the Central Beareau of Statistics (BPS), Central Bank of Indonesia and other sources relevant to the study.

\section{The Structural Equation Model}

$\mathrm{X}$ in Fig. 1 is the standardized regression coefficients. The reason the use of standardized structural equation is due to the values of the variables that exist in the study had a different unit of measured. Therefore, expressed in terms of the standardized regression coefficient, the equations do not have intercept for, so that the amount of structural equation coefficient is equal to the number of independent variables. Furthermore, based on the operational framework of the research path diagram the three sub-structures can be formed are firstly, the sub-structure stating causality of variable Ownership Structure (OS), Investment (INV), share liquidity (LIS), Share Risk (SR) and Corporate Governance (CG) to Operating Performance (OP); Second, sub- structure stating causality of variable OS, IVTSI, LIS and SR to CG; Third, the sub-structure stating causality of variable OS, IVTSI, LIS, SR and CG, OP to Firm Value (FV). Furthermore, on the basis of the three sub- structures have been identified arranged three standardized structural equation, as follows:

$$
\begin{aligned}
Y 1 & ={ }^{P} Y_{1} X_{1} \mathrm{OS}+{ }^{P} Y_{1} X_{2} I N V+{ }^{P} Y_{1} X_{3} L I S+{ }^{P} Y_{1} X_{4} S R+{ }^{P} Y 1 Y 2 C G+{ }^{\varepsilon} 1 \\
Y 2 & ={ }^{P} Y_{2} X_{1} O S+{ }^{P} Y_{2} X_{2} I N V+{ }^{P} Y_{2} X_{3} L I S+{ }^{P} Y_{2} X_{4} S R+{ }^{\varepsilon} 2 \\
Y 3 & ={ }^{P} Y_{3} X_{1} \mathrm{OS}+P Y_{3} X_{2} I N V+{ }^{P} Y_{3} X_{3} L I S+{ }^{P} Y_{3} X_{4} S R+{ }^{P} Y_{3} Y_{1} O P \\
& +{ }^{P} Y_{3} Y_{2} C G+{ }^{\varepsilon} 3
\end{aligned}
$$

\section{Variables of the Study}

The study follows the framework of Isshaq (2009) uses the ownership structure, investment, share liquidity, share risk, operating performance, corporate governance as exogenous variable effect on the firm value. We present the description of these variables and their measurement in this section.

\section{Firm Value; Endogenous Variable}

Endogenous dependent variable is the value of the company/firm value is a reflection of the level of success of the company in managing its resources in year t. The variable that is indicator company success in increasing the value measured by Economic Value Added (EVA). EVA measures the value-added (value creation) generated a company by way of reducing the burden of the cost of capital (cost of capital) arising from the investment made. According to Stewart (1991) EVA formulated as follows:

$$
\begin{aligned}
& \text { ECONOMIC VALUE ADDED } \\
& (\text { EVA }) ;(r-c) X \text { Capital } \\
& \text { NOPAT - (C X Capital })
\end{aligned}
$$

\section{Ownership Structure (OS); Exogenous Variable}

Ownership structure are denoted by $\mathrm{X} 1$ is defined as the proportion of ownership of shares held by managers and employees (managerial ownership) in the company, which is set in percentage (Isshaq, 2009), is formulated as follows:

$$
O S=\sum \text { ownership shares by manager }+ \text { employees }
$$

\section{Investment (INVT)}

Investment are denoted by $\mathrm{X} 2$ measured by using the ratio of Book Value of Equity Market (MBVE). Chosen market-to-book ratio as a proxy variable investment with the premise that the market assesses the return of an investment in the future of the company is greater than the expected return of equity. MBVE measured by dividing the value of the total equity market capitalization of the company (Machfoedz and Suranta, 2003):

$$
M B V E=\frac{\text { Market capitalization }}{\text { Total equity }}
$$

\section{Stock Liquidity (SL)}

Exogenous variable is further denoted X4 liquidity shares measured from the large number of shares traded on the floor of the Indonesia Stock Exchange at the end of the year in the 2000-2010 time frame. Used to measure or proxy for stock turnover (share turnover). Rotation of stock is trading volume shares of a company at the end of the year divided by the number of shares outstanding at the end of the year, using the unit measure of \%. The use 
of this measure in accordance with the measure used by Chordia et al., 2003; Ogden et al., 2003; Ma, 2003; Levine and Schmukler, 2006:

$$
\text { Share } T=\frac{\text { Trading volume share }}{\text { Number of share outstanding }}
$$

\section{Risk Stock (SR)}

Stosk risk as (X4) as an Exogenous variable measured by systematic risk (beta) is formulated as follows:

$$
\mathrm{R}_{\mathrm{it}}=\dot{\alpha}_{\mathrm{i}}+\beta_{\mathrm{i}}\left(\mathrm{R}_{\mathrm{mt}}\right)+{ }^{\varepsilon_{\mathrm{t}}}
$$

Where:

$$
\begin{aligned}
& R i t=\frac{I H S G_{t}-I H S G_{t-1}}{I H S G_{t-1}} \\
& R i t=\frac{P_{t-P t-1}}{P_{t-1}}
\end{aligned}
$$

IHSG = Indeks harga saham gabungan (Indonesian stock price index)

$\mathrm{Ri}=$ Rate of profit stock $\mathrm{i}$ to the time $\mathrm{t}$

$\mathrm{Rmt}=$ Rate of return market index at time $\mathrm{t}$

\section{Operating Performance (OP)}

Intervening endogenous variables are denoted with the operating performance is Y1 measured by the ratio Operating Income Return on Investment (OIROI) that is the ratio between Earnings Before Interest and Taxes (EBIT) divided by total assets:

$$
O I R O I=\frac{\text { Earning Before Interest and Taxes }(E B I T)}{\text { Total asset }}
$$

\section{Corporate Governance (CG)}

Corporate governance exogenous variables are then given notation $\mathrm{Y} 2$.

According to Isshaq (2009) corporate governance is proxied by the size of the board of directors or board size. The size of the board of directors here is the number of members of the board of directors in the company, which is specified in number of units. Isshaq (2009) is formulated as follows:

$$
\text { Bdsize }=\log \Sigma \text { board members }
$$

\section{Analysis}

\section{Regression Coefficient}

There are fifteen (15) hypothesized paths in the model. These pathways describe hypothsized be tested, more on Table 1.

Overall a good path coefficients directly influence or indirect influence can be seen in Fig. 1.

\begin{tabular}{|c|c|c|c|c|}
\hline & $\begin{array}{l}\text { Regression } \\
\text { weight estimate }\end{array}$ & S.E & CR & $\mathrm{P}$ \\
\hline OS OP & 0.075 & 0.272 & 2.434 & 0.015 \\
\hline INVT OP & -0.012 & 0.001 & -0.389 & 0.697 \\
\hline LS OP & 0.013 & 0.047 & 0.440 & 0.660 \\
\hline SR OP & -0.066 & 0.041 & -2.162 & 0.031 \\
\hline CG OP & -0.011 & 0.433 & -0.366 & 0.714 \\
\hline OS CG & 0.080 & 0.049 & 2.618 & 0.009 \\
\hline INVT CG & -0.030 & 0.002 & -0.989 & 0.322 \\
\hline LS CG & -0.047 & 0.074 & -1.544 & 0.123 \\
\hline SR CG & -0.013 & 0.065 & -0.420 & 0.674 \\
\hline OS FV & 0.003 & 0.265 & 0.115 & 0.908 \\
\hline INVT FV & 0.007 & 0.019 & 0.255 & 0.798 \\
\hline LS FV & -0.076 & 0.001 & 2.812 & 0.005 \\
\hline SR FV & -0.024 & 0.045 & -0.875 & 0.382 \\
\hline OP FV & 0.024 & 0.040 & -1.332 & 0.183 \\
\hline CG FV & 0.464 & 0.030 & 17.183 & $<0.050$ \\
\hline
\end{tabular}

Table 1. Critical ratio and probability: Ownership structure, investment, liquidity shares, share risk, operationg performance and corporate governance and value manufacturing companies listed in Indonesia stock exchange

Source: Path analysis output

\section{Discussion}

Ownership structure positively significant effect on the operating performance. Therefore concluded that the hypothesis la was received, the higher the ownership structure, the higher the company's operating performance. The results of this study indicate that there is a difference for companies that have the effect of ownership structure where most of the shares owned by the company's employees and managers who have ownership structures that most of the shares not owned by the employee and the manager, or in other words its holdings concentrated. Due to the significant mean difference conjunction ownership structure will significantly affect the performance of the operation indicated by the company's return on investment. Ownership structure of the parameter estimates are significantly positive. This suggests that greater managerial ownership will be able to improve the performance of the operation in this case is able to increase operating income return on investment. Research data shows that $73 \%$ of manufacturing companies that have been the object of research by the employee stock ownership and manager of over $50 \%$. This indicates that the manufacturing companies in Indonesia realizes that in order to achieve a high level of OIROI much needed role and involvement of employees and managers.

Test results are not statistically investment of significant effect on the level of less than $5 \%$ (cr $=$ -0389 ; with sig- $t=0.697$ ) on the operating performance. Based on statistical tests mentioned above, the investment does not affect the operating performance. Therefore concluded that the hypothesis $1 \mathrm{~b}$ unacceptable, the higher investment, the lower the company's operating performance. In other words, the operating performance is not determined by the percentage change in the market to book value of equity. 
The test results are statistically no effect on share liquidity level of significant less than $5 \%(\mathrm{cr}=0.440$; with sig- $\mathrm{t}=0.660$ ) on the operating performance. Thus, based on statistical tests mentioned above, stock liquidity does not affect the operating performance. Therefore concluded that the hypothesis 1c unacceptable. This means that its liquid a stock is not effective due to the involvement of the shareholders on efficient management and investment decisions are not made based on the information received by the investors on the stock price so there is no opportunistic managerial actions that can stimulate the process of trading.

The results show the value of the beta coefficient of -0.066 proven systematic risk significant effect with the negative direction of the company's operating performance. The results of this study are not consistent with the hypothesis and also in line with the economic theory of argument, that the risk of stocks positive effect on the operating performance of the company. The test results are statistically negative effect on the stock risk of significant levels of less than $5 \%(\mathrm{cr}=-2162$; with sig $\mathrm{t}=0.031$ ) of the company's operating performance. Thus, based on statistical tests mentioned above, the systematic risk of a significant effect on the operating performance of the company, the higher the risk the lower the stock performance of the company's operations, thus concluded that the hypothesis is accepted. Direction of the negative relationship between risk and operating performance shares, meaning there is a difference between effect of a high-risk stock with low operating performance. High-low risk will greatly affect investors' shares at the time of taking a decision, whether to invest or not. Investors, both individuals and companies will be very careful, in this case categorized in the type of investors who refuse risk (risk adverse).

The test results are statistically significant positive effect of ownership structure on the level of significant less than $5 \%(\mathrm{cr}=2618$; with sig-t $=0.009)$ on corporate governance. Thus, based on statistical tests mentioned above, a significant effect of ownership structure positively to corporate governance. Therefore concluded that the hypothesis 2 a received that the higher ownership structure, the higher company's corporate governance.

Test results are not statistically investment of significant effect on the level of $5 \%(\mathrm{cr}=-0.989$; with sig-t $=0.322$ ) on corporate governance. Thus, based on statistical testing, no effect on corporate governance, so it can be concluded that the hypothesis 2 b.un acceptable. The results of this study provide empirical understanding for investors that rising MBVE corporate governance tends to decrease, although the decrease was not statistically significant. This condition is due to an expectation of future investment, meaning that investors prefer profits in the future, for example, the result of a dividend at the end of the period on capital gains, so in the short term has no effect on corporate governance. Management generally see economic investment as a long term prospect, so the impact of current investments can later be felt in the future. The poor implementation of corporate governance, investor confidence dropped caused that will ultimately shift their funds to other companies.

Test results are not statistically significant negative effect on the investment of significant level of $5 \%$ (cr $=$ -1544 ; with sig- $t=0.123$ ) on corporate governance. Thus, based on statistical testing, share liquidity has no effect on corporate governance, so it can be concluded that the hypothesis 2c unacceptable. The results of the study Tadesse (2005) which examines the relationship between share liquidity to conclude that corporate governance policies to improve the transparency and efficiency of markets such as trade reporting requirements and better handling of orders that will help increase the effectiveness of secondary market liquidity of the share and affect the improvement of corporate governance.

Test results are not statistically share risk level of significant at $5 \%(\mathrm{cr}=-0989$; with sig- $\mathrm{t}=0.1322)$ on corporate governance. Thus, based on statistical testing, the risk of the share has no effect on corporate governance, so it can be concluded that the hypothesis $2 \mathrm{~d}$ unacceptable. This finding is in line with the things that a principle in the application of corporate governance, better known by the OECD Principles of corporate governance which emphasizes disclosure, accountability, responsibility, independence and equality and fairness. Which is the application of corporate governance risk is the risk faced by minority shareholders when the majority shareholders can collude with management to take over the assets of the company at the expense of minority shareholders.

The test results were statistically ownership structure has no effect on the level of significant $5 \%(\mathrm{cr}=0.115$; with sig-t $=0.908$ ) on firm value. Thus, based on statistical testing, ownership structure has no effect on firm value, so it can be concluded that the hypothesis $3 \mathrm{a}$ unacceptable. This finding is in line with Fama and Jensen (1983) argue that managers will always insist on the best results are achieved through the labor market, capital market, the market for products without leaving parts stock holding. Consequently there is no systematic relationship between ownership structure and firm value can be expected. Demsetz and Lehn (1985) which uses variable ownership structure as endogenous variables and found no relationship between ownership structure with the level of profit.

The test results are statistically positive effect of investment and not significant at the 5\% level of significant ( $\mathrm{cr}=0255$; with sig-t $=0.798$ ) on firm value. The investment does not affect the value of the company, so it can be concluded that the hypothesis $3 \mathrm{a}$ 
unacceptable. The results of this study are not in line with Gaver and Gaver (1993), where future investment options are not solely with the projects that are supported by research and development activities, but also with the ability of the company more opportunity to exploit takes advantage compared to other companies in a similar industry group.

The test results are statistically negative influence stock liquidity at the $5 \%$ level of significant ( $\mathrm{cr}=-2812$; with sig-t $=0.005$ ) on firm value. Stock liquidity negatively affect the value of the company, so it can be concluded that the hypothesis $3 \mathrm{c}$ be accepted It can be explained that it could happen, which shares a low turnover illiquid but traded at high prices. This is due to investors at the company's fundamentals look pretty good and safe to invest. Because it shares so investors always look for the stock price to be expensive and bring high returns. So although share with low liquidity but because it promises a high return, it will affect the firm value.

Test results are not statistically stock risk level of significant at less than $5 \%(\mathrm{cr}=-0875$; with sig- $\mathrm{t}=$ 0.382 ) on firm value. Thus, based on statistical tests mentioned above, the risk of the share has no effect on firm value. Therefore concluded that the hypothesis $3 \mathrm{~d}$ unacceptable. The results of this study contribute that systematic risk can't be used to predict and explain the firm value, because of the test results were not statistically significant at the significant level of less than $5 \%$. No significant effect of systematic risk on firm value due to no signal is captured by the market participants to systematic risk.

The test results were statistically -1332 beta coefficient and sig- $t=0.183$ indicates that the company's operating performance has no effect on firm value. Thus the hypothesis $3 \mathrm{e}$ is unacceptable. Test results are inconsistent with previous estimates, signaling theory and argument, that the performance of the company is a presence signal return of investment. Expectation of return is no positive response by the market participants so as to increase the company's value. The results of this study contribute to the operating performance of companies that can't be used to predict and explain the value of the company.

The test results were statistically corporate governance and significant positive effect on the level of significant $5 \%(\mathrm{cr}=17183$; sig-t value $=<0.05)$ to the value of the company. Thus, based on statistical testing, corporate governance and significant positive effect on firm value, so it can be concluded that the hypothesis $3 \mathrm{f}$ accepted. Corporate governance as measured by the number of board of directors is one of the mechanisms adopted in controlling agency's conflicts company. Described in agency theory, Byrd et al. (1998) that control the agency conflict can be performed by several mechanisms such as: Compensation, share ownership, the board of directors, the managerial labor market, the market for corporate control. Broussard et al. (2004) states that there is a relationship between incentives Chief Executive Officer (CEO), free cash flow and investment. The statement indicates a sensitivity to the incentive manager (performance pay) can reduce agency problems.

\section{Conclusion}

Firm value of the company listed in Indonesia Stock Exchange is directly influenced by corporate governance and stock liquidity. This means that the success of implementing good corporate governance can create added value for the company. While the ownership structure, investment, share risk and operating performance has no effect on firm value.

Ownership structure has a direct influence on the performance of the operation, thus directly differences in the ownership structure will result in an increase or decrease in operating performance. Ownership structure has a direct influence on corporate governance means good or bad corporate governance is largely determined by the structure of corporate ownership.

Stock liquidity have a negatively affect to the firm value, which means that the illiquid share of a company is only one consideration in the decisionmaking of investors to buy shares. Thus the hypothesis that stock liquidity effect on corporate value is acceptable. Risk stock has a negative effect on performance of the operation. This means a high risk investment decision will affect both individual and corporate investors. So that investors can be categorized in the group risk adverse.

\section{Funding Information}

This article is based on research results in achieving a doctorate degree on the Hasanuddin University, Makassar, Indonesia. This research has received financial support from the post-graduate scholarship program (BPPS) directorate general of higher education Indonesian National Education Department. All the remaining errors are my only resposibility. Therefore I would like to pay special thankfulness and appreciation to the person bellow who made my research succesfull and assisted me every point to cherish my goal: My supervisor, Prof. Dr. Muhammad Ali, SE, MS, for his support and assistance. His encouragement made it possible to achieve my goal. My Assistant supervisor, Prof Dr. Cepi Pahlevi, SE, MSi and Dr. Muhammad Yunus Amar, SE, MT, whose help and sympathetic attitude at every point during my research helped me to work in time. Prof. Dr. Djabir Hamzah, MA, Head of the Economics Program Study of Doctoral Degree, Faculty of Economics and Business, University of Hasanuddin and Prof. Dr. D.P.E. Saerang, SE, M Com (Hons), Dean 
of the Faculty of Economics and Business Sam Ratulangi University, whose reminder and constant motivation encourage me to meet the deadline.

\section{Author's Contributions}

Maryam Mangantar: That who has participated in all experiments, coordinated the data-analysis and contributed to the writing of the manuscript.

Muhammad Ali: That who has made considerable contributions to conception and research design and make the article or reviewing it critically for significant intellectual content.

\section{Ethics}

This paper is the result of the work of I own, free from the imitation of the work others. Quotes, opinion and writing of other appointed in accordance with the ways of writing scientific paper that apply. If a later proven or provable that in this study contained the characteristic of plagiarism and other form of immitation in violation of the rules, then I'm a willing to accept sanction for such action.

\section{References}

Aggarwal, R.K. and A.A. Samwick, 1999. The other side of the trade-off: The impact of risk on executive compensation. J. Political Econ., 107: 65-105. DOI: $10.1086 / 250051$

Amman, M., O. David and M.M. Schmid, 2009. Corporate governance and firm value: International evidence. Swiss Institute of Banking and Finance, University of St. Gallen.

Anderson, C.R., S.A. Mansi and D.M. Reeb, 2003. Founding family ownership and the agency cost of debt. J. Financial Econ., 68: 263-285. DOI: $10.1016 / \mathrm{S} 0304-405 \mathrm{X}(03) 00067-9$

Barnhart, S. and S. Rosenstein, 1998. Board composition, managerial ownership and firm performance: An empirical analysis. Financ. Rev., 33: 1-16. DOI: 10.1111/j.1540-6288.1998.tb01393.x

Bhide, A., 1993. The hidden costs of stock market liquidity. J. Financ. Econ. 34: 31-51. DOI: 10.1016/0304-405X(93)90039-E

Black, B.S., A.G. de Carvalho and E. Gorga, 2003. When corporate governance elements predict firm value: Evidence from Brazil. Soc. Sci. Res. Netw. Electronic.

Brigham, E.F. and J.F. Houston, 2003. Fundamentals of Financial Management. 4th Edn., Thomson/SouthWestern, Mason, ISBN-10: 0324258860, pp: 400.

Broussard, J.P., S.A. Buchenroth and E.A. Pilotte, 2004. CEO incentives, cash flow and investment. CFA Digest, 33: 251-270. DOI: 10.2469/dig.v34.n4.1558
Byrd, J., R. Parrino and G. Pritsch, 1998. Stockholdermanager conflicts and firm value. Financ. Anal. J., 54: 31-40. DOI: 10.2469/faj.v54.n3.2177

Cho, D.S. and J. Kim, 2007. Outside directors, ownership structure and firm profitability in Korea. Corporate Governance: An Int. Rev., 15: 239-250. DOI: $10.1111 /$ j.1467-8683.2007.00557.x

Cho, M.H., 1998. Ownership structure, investment and the corporate value: An Empirical analysis. J. Financ. Econ., 47: 103-121. DOI: $10.1016 / \mathrm{S} 0304-405 \mathrm{X}(97) 00039-1$

Chordia, T., L. Shivakumar and A. Subrahmanyam, 2003. Liquidity dynamics across small and large firms.

Cole, R.A. and H. Mehran, 1998. The effect of changes in ownership structure on performance: Evidence from the thrift industry. J. Financial Econ., 50: 291-317. DOI: $10.1016 / \mathrm{S} 0304-405 X(98) 00039-7$

Damodaran, A., 2006. Investment Valuation, 2nd Edn.

Demsetz, H. and B. Villalonga, 2001. Ownership structure and corporate performance. J. Corporate Finance, 7: 209-233. DOI: $10.1016 / \mathrm{S} 0929-1199(01) 00020-7$

Demsetz, H. and K. Lehn, 1985. The structure of corporate ownership. J. Political Econ., 93: 1155-1177.

Drobez, W., 2003. The impact of corporate governance on firm performance.

Eisenberg, T., S. Sundgren and M.T. Wells, 1998. Larger board size and decreasing firm value in small firms. J. Financial Econ., 48: 35-54. DOI: $10.1016 / \mathrm{S} 0304-405 \mathrm{X}(98) 00003-8$

Fama, F.E., 1978. The Effects of a Firm's investment and financing decisions on the welfare of its security holders. Am. Econ. Rev., 68: 272-284.

Fama, E. and M. Jensen, 1983. Separation of ownership and control. J. Law Econ., 26: 301-325.

Fuers, O. and S.H. Kang, 2000. Corporate governance, expected operating performance and pricing.

Gaver, J.J. and K.M. Gaver, 1993. Additional evidence on the association between the investment opportunity set and corporate financing, dividend and compensation policies. J. Account. Econ., 16: 125-160. DOI: 10.1016/0165-4101(93)90007-3

Gugler, K., C.D. Mueller and B.B. Yurtoglu, 2004. Marginal q, Tobin's q, cash flow and investment. Southern Econ. J., 70: 512-531. DOI: $10.2307 / 4135328$

Huey, J., 1994. The new post-heroic Leadership. Fortune, 21: 42-50.

Isshaq, Z., 2009. Corporate governance, ownership structure, cash holding and firm value on the Ghana stock exchange. J. Risk Finance, 10: 488-499. DOI: $10.1108 / 15265940911001394$

Iturriaga, F.J.L. and J.A.R. Sanz, 2001. Ownership structure, corporate value and firm investment: A simultaneous equations analysis of Spanish companies. J. Manage. Governance, 5: 179-204. DOI: $10.1023 / \mathrm{A}: 1013078225905$ 
Jain, B.A. and O. Kini, 1994. The post-issue operating performance of IPO firms. J. Finance, 49: 1699-1726. DOI: $10.2307 / 2329268$

Jensen, M.C. and W.H. Meckling, 1976. Theory of the firm: Managerial behavior, agency costs and ownership structure. J. Financ. Econ., 3: 305-360. DOI: $10.1016 / 0304-405 X(76) 90026-X$

Jung, J. and W. Lee, 2009. Ownership structure, corporate governance and firm value: Evidence from China listed company.

Kaen, F.R., 2003. A Blueprint for Corporate Governance: Strategy, Accountability and the Preservation of Shareholder Value. 1st Edn., AMACOM Div American Mgmt Assn, New York, ISBN-10: 0814426980, pp: 256.

Kaplan, S., 1989. The effects of management buyouts on operating performance and value. J. Financial Econ., 24: 217-254. DOI: 10.1016/0304-405X(89)90047-0

Keown, A.J., J.H. Martin and D.F. Scott, 2004. Financial Management: Principles and Applications. 10th Edn., Prentice Hall, ISBN-10: 0131450654, pp: 880.

Leland, H. and D.H. Pyle, 1977. Information asymmetries, financial structure and financial intermediation. J. Finance, 32: 371-387.

DOI: $10.1111 / \mathrm{j} .1540-6261.1977 . t b 03277 . x$

Lemmon, M.L. and K.V. Lins, 2003. Ownership structure, corporate governance and firm value: evidence from the East Asian financial crisis. J. Finance, 58: 1445-1468.

DOI: $10.1111 / 1540-6261.00573$

Levine, R. and S.L. Schmukler, 2006. Internationalization and stock market liquidity. Rev. Finance, 10: 153-187. DOI: $10.1007 / \mathrm{s} 10679-006-6981-7$

Loderer, C. and L. Roth, 2005. The pricing discount for limited liquidity: Evidence from SWX Swiss Exchange and the Nasdaq. J. Empirical Finance, 12: 239-268. DOI: 10.1016/j.jempfin.2003.12.001

Lyandres, E., L. Sun and L. Zhang, 2008. The new issues puzzle: Testing the investment-based explanation. Rev. Financ. Stud., 21: 2825-2855. DOI: $10.1093 / \mathrm{rfs} / \mathrm{hhm} 058$

Ma, G., 2003. The anatomy of daily stock turnover. International Business School, Brandeis University, United States.

Machfoedz, M. and E. Suranta, 2003. An analysis of ownership structure, firm value, investment, firm size and board of director Proceedings of the 7th National Symposium of Accounting, (NSA'03), Surabaya, Indonesia.

Mcconnell, J.J. and H. Servaes, 1990. Additional evidence on equity ownership and corporate value. J. Financ. Econ., 27: 595-612.

DOI: $10.1016 / 0304-405 X(90) 90069-C$
Mikkelson, W.H., M.M. Partch and K. Shah, 1997. Ownership and operating performance of companies that go public. J. Financ. Econ., 44: 281-307. DOI: $10.1016 / \mathrm{S} 0304-405 X(97) 00006-8$

Morck, R., A. Shleifer and R.W. Vishny, 1988. Management ownership and market valuation: An Empirical Analysis. J. Financial Econ., 20: 293-315. DOI: $10.1016 / 0304-405 X(88) 90048-7$

Muscarella, C.J. and M.R. Vetsuypens, 1990. Efficiency and organizational structure: A Study of Reverse LBOs. J. Finance, 45: 1389-1413. DOI: $10.1111 / \mathrm{j} .1540-6261.1990 . t b 03720 . \mathrm{x}$

Ogden, J.P., F.C. Jen and P.F. O'Connor, 2003. Advanced Corporate Finance: Policies and Strategies. 1st Edn., Prentice Hall, Upper Saddle River, N.J., ISBN-10: 0130915688, pp: 702.

Ross, S.A., R.W. Westerfield and J.F. Jaffe, 1993. Corporate Finance. 3rd Edn., Irwin, Homewood, IL., ISBN-10: 9780256094879.

Setiawan, A., 2004. An empirical analysis of debtequity choice in Indonesian companies. $\mathrm{PhD}$ Thesis, Universiti Sains Malaysia, Malaysia.

Short, H., H. Zhang and K. Keasey, 1999. The link between dividend policy and institutional ownership. J. Corporate Finance, 8: 105-122. DOI: 10.1016/S0929-1199(01)00030-X

Siallagan, H. and M. Machfoedz, 2006. Corporate governance mechanism, earning quality and firm value. Proceedings of the 9th National Accounting Symposium, (NAS'06).

Smith, A.J., 1990. Corporate ownership structure and performance: The case of management buyouts. J. Financial Econ., 27: 143-164. DOI: 10.1016/0304-405X(90)90024-T

Stewart, G.B., 1991. The Quest for Value: A Guide for Senior Managers. 1st Edn., HarperBusiness, New York, ISBN-10: 0887304184, pp: 781.

Tadesse, S., 2005. Stock Markets Liquidity, Corporate Governance and Small Firms. Working Paper No. 883, William Davidson Institute.

Watts, R.L. and J.L. Zimmerman, 1990. Positive Accounting Theory: A ten year perspective. Account. Rev., 65: 131-156.

Wibisono, C., 1998. Tracing the Roots of Indonesia Crisis, Gramedia Publisher, Jakarta. 